文
論
UDC $\quad 621.746 .047: 620.192 .45: 669.18 .046 .5$

\title{
連続鋳造における外来性介在物の起源とその減少対策
}

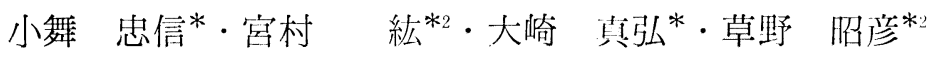

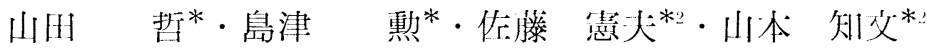

\section{Source of Exogeneous Inclusions and Reduction of Their Amount in Continuous Casting Process}

\author{
Tadanobu Komai, Kou Mryamura, Masahiro Oosaki, Akihiko Kusano, \\ Satoshi Yamada, Isao SHimazu, Norio SAto, and Tomohumi Yamamoto
}

\footnotetext{
Synopsis :

Investigations to produce clean steel for draw and ironing cans in continuous casting process were carried out.

Results obtained are as follows :

(1) Inclusions which cause flange cracks in manufacturing draw and ironing cans are $50 \sim 150 \mu \mathrm{m}$ in size and $\mathrm{CaO}-\mathrm{Al}_{2} \mathrm{O}_{3}$ in compositions, which can be fairly well detected by the magna-flux method.

(2) $\mathrm{CaO}-\mathrm{Al}_{2} \mathrm{O}_{3}$ inclusions are originated from slag which is deoxidized by $\mathrm{Al}$ in molten steel, the content being about $0.005 \%$ or above.

(3) Main source of the above-mentioned inclusions is tundish-slag, which is spattered into molten steel by the stream of the next ladle in continuous casting.

(4) Good clean steel for draw and ironing cans can be produced by means of either large tundish with dams or reladling method (LLTM process)

(5) The theoretical model to explain the effect appointed out in (4) was proposed.
}

\section{1. 緒言}

連続鋳造プロセスは，その本質的に有する連続性の利 点を生かして生産性の向上はもとより, 鋼の品質の改 恙, 安定に大きな貢献をしている. 寸なわち, 現在では 生産技術として幅可变技術1) 3) の開発による多連鋳技術 および高速鋳造技術等4) 生産性の向上がはかられている。一方，高い品質が要求 されている高級鋼の連鋳化に際しては，介在物起因の火 伯がしばしば問題となつている6) 8) と加光, 需要家から の品質要求は，作々きびしくなり鋼の使用月的によつて は, 約 $50 \mu \mathrm{m}$ 待の微練な介在物まで問題となつてい る ${ }^{7) \sim 9)}$.

従来の研究において, 連続鋳造における介在物起源 は, 溶鋼の空気酸化 ${ }^{10)}$ 14), 取鍋スラグ15), タンディッ シュスラグ6)13) あるいは鋳型内パウダー12)13)16)，タンデ ィッシュノズルの溶損 ${ }^{12)}$ などに起因する外来性介在物が 寿体であり，これらの混入比率を確認した研究例があ
$ろ^{8)}$ が，いずれも定常鋳造域における品質问上について の研究が主であつた。しかし連々鋯の場合においては, 定常状態の鋳片之，鍋交換版などの非定常状態のいわゆ る継目鋳片とは，介在物の混入比㖣も買なり，束た非定 常状態部に打ける品質対策が定常状柋部の品質をも大き く左右している。この問題は $50 \mu \mathrm{m}$ 径程度の微練な介 在物において蹎著である。

本研究は，このような観点から $50 \mu \mathrm{m} \sim 150 \mu \mathrm{m}$ 径程 度の介在物が問題となる絞りとしごきが: (Draw and Ironing）により成形される 2 ピー久住（以トDI 优） 用素忉を対象として，この材料における介伍物の起源を

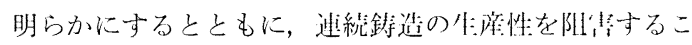
となく効果的な介在物低減泣について研究したものであ z.

\section{2. 調 查の 概 要}

調查の対象とした鋼種はDI仿用素材であり, Table 1 に示す成分の低芿アルミキルド鋼である。使用した連鋳

*2 䉼山术慗鉄 (怢) 分幡製鉄所 (Yawata Works, Nippon Stecl Corp.) 
Table 1. Chemical composition cf steel.

\begin{tabular}{|c|c|c|c|c|c|c|}
\hline & $\mathrm{C}$ & $\mathrm{Si}$ & $\mathrm{Mn}$ & $\mathrm{P}$ & $\mathrm{S}$ & sol.Al \\
\hline wt.\% & $\begin{array}{c}0.03 \sim \\
0.05\end{array}$ & 0.02 & $\begin{array}{c}0.20 \sim \\
0.30\end{array}$ & $\mathbf{0 . 0 2 5}$ & 0.015 & $\begin{array}{c}0.030 \sim \\
0.150\end{array}$ \\
\hline
\end{tabular}

Table 2. Dimensions of casting machine and casting conditions.

\begin{tabular}{|c|lr|c|c|}
\hline \multicolumn{2}{|c|}{ Casting machine } & \multicolumn{2}{c|}{ A } & B \\
\hline \multicolumn{2}{|c|}{ Machine type } & \multicolumn{2}{c|}{ Curved type } \\
\hline \multicolumn{2}{|c|}{ Machine radius $(\mathrm{m})$} & \multicolumn{2}{c|}{10.5} \\
\hline \multirow{2}{*}{ Slab size } & Width & $(\mathrm{mm})$ & \multicolumn{1}{|c|}{} & \multicolumn{2}{c|}{ 800 2080 } & $1700 \sim 1800$ \\
& Thickness & $(\mathrm{mm})$ & 200 & 245 \\
\hline \multirow{2}{*}{ Casting speed } & Middle position $(\mathrm{m} / \mathrm{min})$ & 1.4 & 1.3 \\
\cline { 2 - 5 } & Connecting position $(\mathrm{m} / \mathrm{min})$ & $1.1 \sim 1.4$ & 1.3 \\
\hline \multirow{2}{*}{ Tundish } & Capacity & $(\mathrm{t})$ & 60 & 15 \\
\cline { 2 - 5 } & Bath depth & $(\mathrm{mm})$ & 1200 & 500 \\
\hline \multirow{2}{*}{$\begin{array}{c}\text { Intermediate } \\
\text { ladle }\end{array}$} & Capacity & $(\mathrm{t})$ & - & 250 \\
\cline { 2 - 5 } & Bath depth & $(\mathrm{mm})$ & - & 2,950 \\
\hline
\end{tabular}

機は, Table 2 に示すようにいずれも曲率半径 $10.5 \mathrm{~m}$ の円孤型スラブ用連鋳機であるが，連鋳機 $\mathrm{A}$ は $60 \mathrm{t}$ 容 量の大型タンディッシェを有し，一方連鋳機 B は取鍋 と同容量 $(250 \mathrm{t}$ ) の中間鍋を配したものである。(以下 LLTM 法と記す.) すなわち, 従来法 (LTM 法と記 す.) に打いては取鍋交換時に, 取鍋一タンディッシュ間の
開放注入状態が一時的に生じるが，LLTM 法に括いて は中間鍋が溶鋼量の調整機能を有するためこの状態が回 避される。

調査は大きく分けて以下に示吉項目について行つた.

（1）製品欠陷部の介在物と検出方法

DI 金加工時に発生したフランジ割れ部の介在物の形 状および組成を EPMA あるいは, 走査型電子顕微鏡に よつて調査した。 またこの種の欠陥を検出する手段とし て磁粉探傷法を用いた。

（2）鋳造工程での介在物の挙動

取鍋，タンディッシュ内溶鋼および鋳片より採取した 試料からスライム法によつて介在物を抽出し，その組成 を調查し，上記欠陷部の介在物組成と対比させた。

（3）連々鋳継目部に和汁る介在物の混入過程

後述するよらに，欠陷部に存在する介在物は製鋼スラ グが主因と考觉られることから，製鋼スラグ（取鍋スラ グ，タンディッシュスラグ）中にトレーサーとして炭酸 ストロンチゥウムを添加し，その挙動について調査し た.さらに，これらの製鋼スラグの変質過程について， タンマン炉を用いた反応実験を行つた.

(4) 実操業調査

前述の連鋳機 $\mathrm{A}$ 抢よびBについての実操業の結果を製 品の磁粉探傷欠陷発生率によつて評価した。

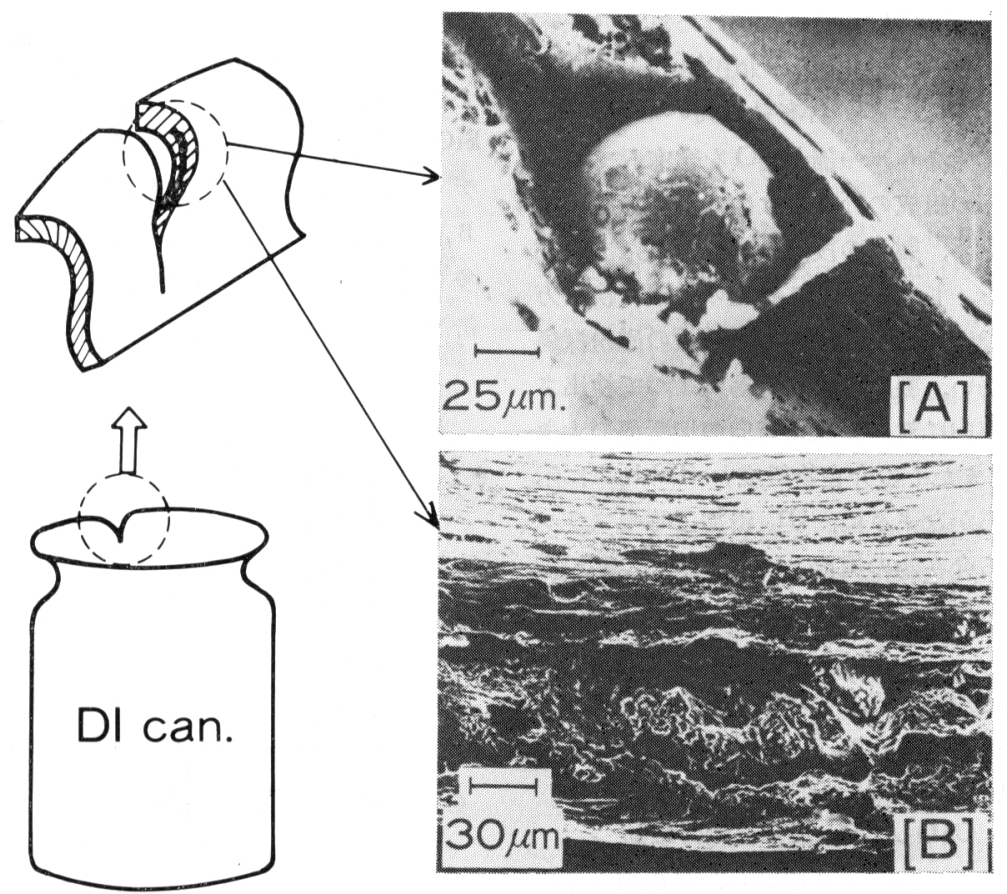

Photo. 1. Inclusions originating frange cracks in draw and ironing. 
Table 3. EPMA analysis of inclusions at the defects.

\begin{tabular}{|l|c|c|c|c|c|}
\hline $\begin{array}{l}\text { Kind of } \\
\text { defects }\end{array}$ & \multicolumn{4}{|c|}{ Chemical composition (\%) } \\
\hline $\begin{array}{l}\text { Frange } \\
\text { Cracks }\end{array}$ & $15 \sim 30$ & $65 \sim 85$ & $\leq 3.6$ & $\leq 1.0$ & $(2 \sim 8)$ \\
\hline $\begin{array}{l}\text { magna-flux } \\
\text { defects }\end{array}$ & $24 \sim 34$ & $55 \sim 73$ & $\leq 1.0$ & $\leq 1.0$ & $(7 \sim 14)$ \\
\hline
\end{tabular}

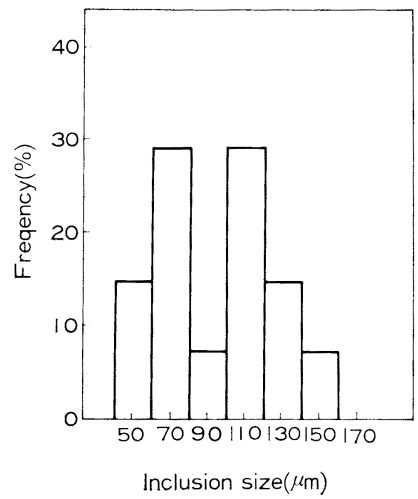

Fig. 1. Size of inclusion detected by the magnaflux method in tin plate.

\section{3. 調 查結 果}

\section{1 製品欠陥部の実態と検出法}

DI 缶加工時のフランジ割れの破面にみられる介在物 の代表例を Photo. 1 亿示与. この介在物の組成は, Table 3 に示すように $\mathrm{Al}_{2} \mathrm{O}_{3}$ 含有量の高い $\mathrm{CaO}-\mathrm{Al}_{2}$ $\mathrm{O}_{3}$ 系介在物が主体であり，一部 $\mathrm{Na}_{2} \mathrm{O}$ を含有している ものも㐫る. これらの組成の介在物は硬いため, 圧延に よつて変形されにくく, 製品の段階でも球形または微細 な塊状の欠宿である. したがつてこの種の欠陥の検出方 法としては原始的ではあるが，抜き取つた板の磁粉探傷 法が，検出精度が高い。製品の磁粉探傷によつて検出さ れた介在物の圧延方向に対し，直角方向の切断部の大き さ分布を Fig. 1 とまたとの介在物組成を Table 3 と示 す.これからも明らかなよらに, DI 缺加工時のフラン ジ割れの原因となる介在物の組成とよく一致し, 磁粉探 傷法は DI 缶加工時の介在物を十分検出し得ることが確 認された。

フランジ割れの起点となる介在物は圧延によつて延び にくい介在物で，その大きさは 50〜150 $\mu \mathrm{m}$ であり， フ ランジ部の板厚（約 $170 \mu \mathrm{m}$ ) の $30 \sim 90 \%$ を占める.

\section{2 鉡造工程での $\mathrm{CaO}-\mathrm{Al}_{2} \mathrm{O}_{3}$ 系介在物の挙動}

鋳片試料からスライム法により抽出した介在物を分類 し Table 4 に示しさらに $\mathrm{CaO}-\mathrm{Al}_{2} \mathrm{O}_{3}-\mathrm{SiO}_{2}$ 系の 3 元
Table 4. Classification of inclusions in cast slab of low carbon $\mathrm{Al}$-killed steel.

\begin{tabular}{|c|c|c|}
\hline Type & Composition of inclusions & $\begin{array}{c}\text { Frequency } \\
(\text { (I) }\end{array}$ \\
\hline A & Ca-Al-Si-(Na)-O & 25 \\
\hline B & Ca-Al-Si-(Na)-O & 10 \\
\hline C & Ca-Al-(Na)-O & 26 \\
\hline D & Si-Ti-Ca-Al-Mn-O & 32 \\
\hline E & Si-O & 8 \\
\hline
\end{tabular}

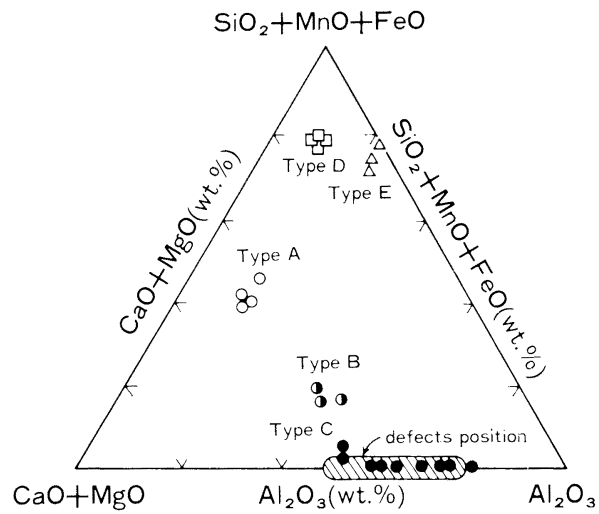

Fig. 2. Phase relation of inclusions extracted from cast slabs.

系状態㘠を Fig. 2 に示したが，5栕颣のタイプに分類 することができた。タイプムの介在物は， $\mathrm{CaO}-\mathrm{Al}_{2} \mathrm{O}_{3}$ $\mathrm{SiO}_{2}$ が主体であり，製鋼スラグ(收鍋スラグまたはタン ディッシュスラグ）の組成とよく一致する。亦たタイブ $\mathrm{B}$ ，タイプ $\mathrm{C}$ の在物は，しだいに $\mathrm{Al}_{2} \mathrm{O}_{3}$ の含有量が 多くなつている。ささらにタイプ Cの介在物は, 前於 DI 缶加工時の割佂部に存在した介在物糺成㧍上び磁粉探傷

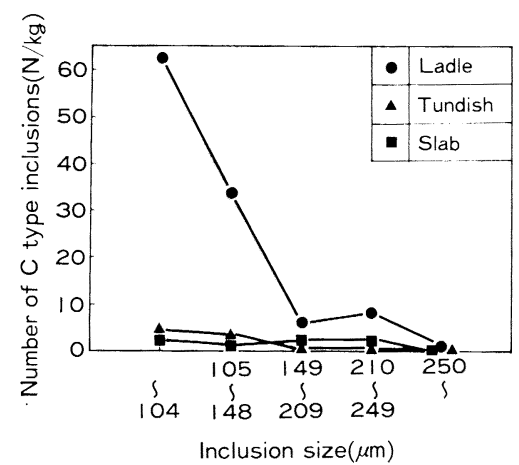

Fig. 3. Change of size distribution of $\mathrm{C}$ type inclusions during continuous casting process. 
欠陷部に存在した介在物組成とよく一致している. タイ プCの介在:物の銑造丁.程での举動は Fig. 3 に示すよう に出鋼後 $\Lambda 1$ 脱酸したあとボトムバブリング 10 分程度 行つた取鍋内溶鋼淌より約 $500 \mathrm{~mm}$ 卜より採取した試 料中にすでに多聶に発生している.さらにこれがタンデ ィッシュ, 鋳片では急激に娍少していることがわかる.

磁粉探傷欠陥の発生の特徵は, 連々鋳の継目部におい て発生率が高くかつ, 連及鋳の回数とともに増大する傾 向をもつている.

\section{3 連々鋳の継目における介在物の混入過程}

連々鋳の継Hに抢ける磁粉探傷欠陷部が主として製鋼 スラグ系の介在物に起因していることは，前述のとおり である。しかしながらその混入過程には次の両者が考光 られ，おの拉のの寄卢度を明らかにするため次のような トレーサー亳験を実施した。

（1）後鍋注入流によるタンディッシュスラグのたた きこみ

（2）先鍋スラグの末期流入

$3 \cdot 3 \cdot 1$ 车験方法

（1）トレーサー実験 I（タソディッシュスラグ）

岑酸ストロンチューム $\left(\mathrm{SrCO}_{3}\right) 35 \mathrm{~kg}$ とウォラステナ イト $35 \mathrm{~kg}$ をく混命し,これを先鍋の鋳造の安定した 時点で取鍋ロングノズルまわりのタンディッシュ湯面上 に投入して先鍋のタンディッシュスラグを $\mathrm{SrO}$ で標識 する一方，鋳型内溶融パウダーを先鍋から後鍋にわたっ て逐時採取し， $\mathrm{SrO}$ 含有量の推移を分析調査した。

（2）トレーサー事験 II（取鍋スラグ）

転炉出鋼末期に炭酸ストロソチューム $270 \mathrm{~kg}$ を取鍋 に投入して取鍋スラグを標識する一方，このチャージは 取鍋涺入完了後タンディッシュ内溶鋼量が定常溶鋼量の $60 \mathrm{t}$ から $40 \mathrm{t}$ になつた時点で No. 2 ストランドの鋳造 を停惦し，No.1 ストランドは 6 t になるまで鋳造を継 続した。鋳型内溶融パウダー中の $\mathrm{SrO}$ 含有量の变化 は，寒験 I と同じ方法で調查した。

なお，雨”尖験の主な鋳造条件は Table 2 の連鋳機 $\mathrm{A}$ に示すと抢りである。 また上記の調查とともにタンディ ッシュ内から溶鋼試料を採取して顕微鏡観察で介在物を 調査する一力, 製品板の磁粉探傷欠陥によつて介在物量 の発生推移を調䍒した。 また EPMA を用い介在物中の $\mathrm{SrO}$ の有無を調查した.

\section{$3 \cdot 3 \cdot 2$ 実験結果}

Fig. 4 および Fig. 5 に鋳型内溶融パウダー中の $\mathrm{SrO}$ 含有量 $(\mathrm{SrO} \%)$ の推移を示した. タンディッシュスラ グのトレーサー実験では後鍋注入開始とともに $(\mathrm{SrO} \%)$ は急激に增加して扣り，継目部ではタンディッシュスラ

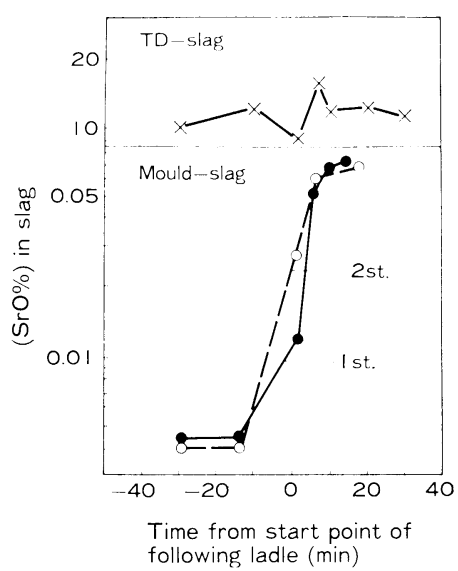

Fig. 4. Change of $(\mathrm{SrO} \%)$ in mould-slag and tundish-slag in the case of experiment I.

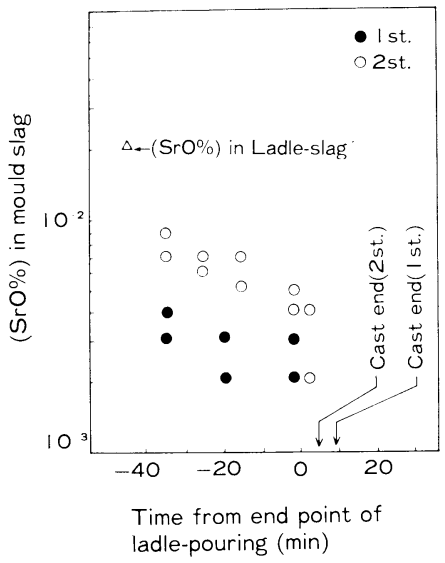

Fig. 5. Change of $(\mathrm{SrO} \%)$ in mould-slag and ladleslag in the case of experiment II.

グがかなり鋳型内に流入することを示している.

これに対して取鍋スラグトレーサー実験では，取鍋の 注入末期において $(\mathrm{SrO} \%)$ が増加する傾向は認められ なかつた。

Fig. 6 に磁粉探傷欠陥の 発生推移を示す. 実験 Iで は後鍋の注入開始とともに磁粉探傷欠陥は急増し，ピー クを形成している．これに対し実験IIでは，タンディッ シュ溶鋼量 $40 \mathrm{t}$ になつた時点で鋳造を停止した No. 2 ストランドは, 取鍋の注入終了時点で磁粉探傷欠陥の発 生ピークがみられるもののきわめて少ない水準である.

またタンディッシュ溶鋼量が $6 \mathrm{t}$ まで鋳造を継続し た，No. 1 ストランドでは，取鍋の注入終了からある時 間を経過したのち，すなわちタンディッシュ溶鋼量が大 幅に減少し始めてから磁粉探傷欠陥が増加している。 


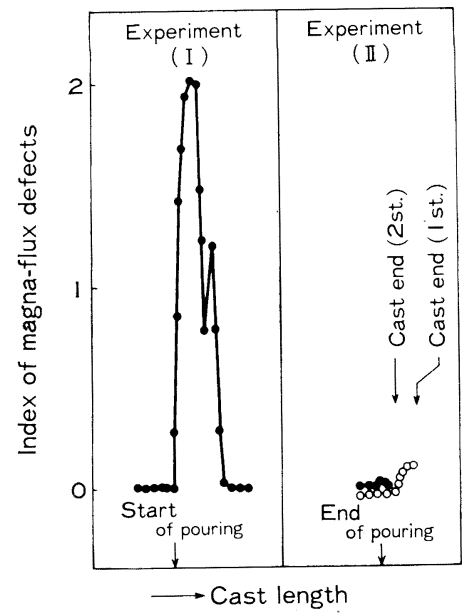

Fig. 6. Change of occurence of magna-flux defects in cast length.

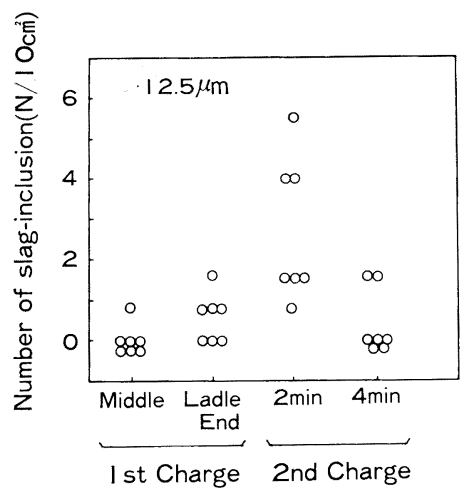

Fig. 7. Change of number of slag-inclusions in molten steel of tundish at a connecting position of casting.

た磁粉探傷欠陷部にみられる介在物の EPMA 調査で は，実験 Iでは 5 例中すべてに $\mathrm{SrO}$ が検出されたのに 対し, 実験IIでは, まつたく検出されなかつた。

Fig. 7 には連々鋳の継目部に和けるタンディッシュ 内溶鋼中のスラグ系介在物量推移を示す．先鍋の注入終 了時点でスラグ系介在物はやや増加するものの，後鍋の 注入開始直後に急增する傾向は，実験 I での $(\mathrm{SrO} \%)$ や磁粉探傷欠樎の傾向と同じである.

したがつて上記結果から明らかなごとく，連々鋳の継 目に打いて問題となる磁粉探傷欠陥の大部分は, タンデ ィッシュスラグの後鍋によるたたきこみに起因している と考觉ることができる.

\section{$3.4 \mathrm{CaO}-\mathrm{Al}_{2} \mathrm{O}_{3}$ 系介在物の生成過程}

前述のように DI 缶加工に拈ける介在物は $\mathrm{CaO}$ -
$\mathrm{Al}_{2} \mathrm{O}_{3}$ 系の介在物が原因であり, 製鋼スラグに起因する と推定される。 そこで, $\mathrm{CaO}-\mathrm{Al}_{2} \mathrm{O}_{3}$ 系介住物の生成過 程について実験窒的な娭讨を行つた。

\section{$3 \cdot 4 \cdot 1$ 実験方法}

Ar 雾团気のタンーン炣を用い，任解鉄約 $700 \mathrm{~g}$ を電 融マグネシアるつぼで溶解し，所定の成分に調整した 後，その上に製鋼スラグ (転炉スラグ，取鍋スラグ，タ ンディッシュスラグ）を添加し，その後 $\mathrm{Al}$ を浴鋼中に 添加したのち一定時間亚に溶鋼の成分变化を調べるとと もに，反応後の各スラグ拉よび鋼中の介在物の組成を調 ベた.

\section{4 .2 結果}

鋼中 $\mathrm{Al}$ によるスラグ中の組成の被这元性は, $\mathrm{FeO}$, $\mathrm{MnO}, \mathrm{SiO}_{2}$, の順となる。 このために $\mathrm{CaO}-\mathrm{Al}_{2} \mathrm{O}_{3}$ 系介 在物の生成反応は， $\mathrm{SiO}_{2}$ の邀元で律速される。 そこで 静止浴（タンマン炉）に拈ける転灯スラグと鋼中 $\mathrm{Al}$ 含 有量と鋼中 $\mathrm{Si}$ の変化および反応珄成物について調查し

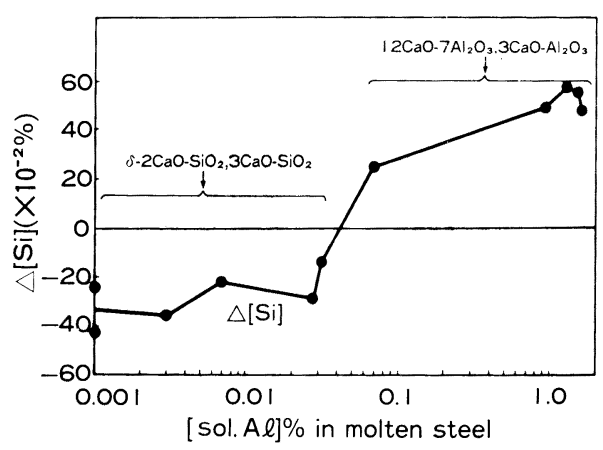

Fig. 8. Effect of sol. $\mathrm{Al} \%$ on change of $\mathrm{Si} \%$ in molten steel and slag composition through slagmetal reaction.

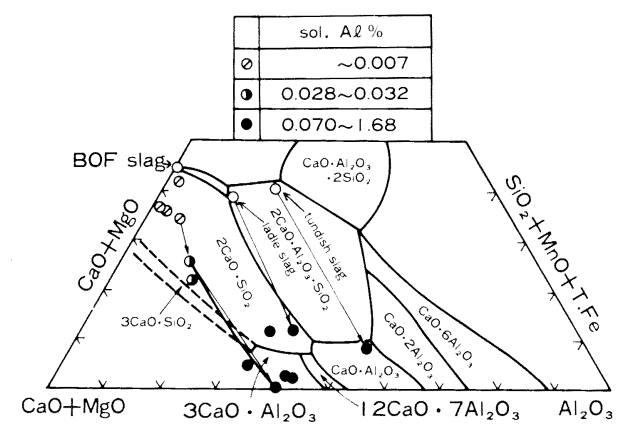

WEIGHT \%

Fig. 9. Change of slag composition by slag-metal reaction in relation to [sol. $\mathrm{Al}] \%$ in steel. (Laboratory test) 


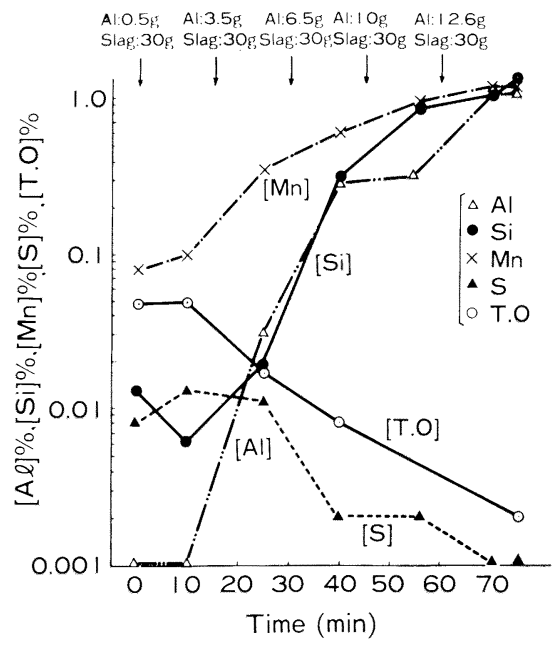

Fig. 10. Change of elements in molten steel by a reaction between slag and $\mathrm{Al}$ in steel.

(Laboratory test)

た. $\mathrm{Al}$ 添川後 60 分経過し反応のほぼ完了した侍点に 敌ける鋼中 $\Lambda 1$ と鋼中 Si の変化との関係を Fig. 8 に 示す. sol.Al が $0.07 \%$ 以上になると初期鋼中 $\mathrm{Si}$ よ り末期銅小 $\mathrm{Si}$ が上多しており，をた，その反応生成物 （スラグ）が $3 \mathrm{CaO} \cdot \mathrm{Al}_{2} \mathrm{O}_{3}, 12 \mathrm{CaO} \cdot 7 \mathrm{Al}_{2} \mathrm{O}_{3}$ の結晶が生 成していることが確涊された．また，溶解後のスラグの 化学分析絬果を $\left(\mathrm{SiO}_{2}+\mathrm{MnO}+\mathrm{T}, \mathrm{Fe}\right)-(\mathrm{CaO}+\mathrm{MgO})$ $-\mathrm{Al}_{2} \mathrm{O}_{3}$ の擬三元采として Fig. 9 亿示す. sol. $\mathrm{Al}$ が $0.007 \%$ 以下では枟炏・ラグの組成近傍の $2 \mathrm{CaO} \cdot \mathrm{SiO}_{2}$ で岗るが， sol.A1 が 0.030\% になると一部還元されて $3 \mathrm{CaO} \cdot \mathrm{SiO}_{2}$ 近傍の組成になつている。 さらに sol. $\mathrm{Al}$ が $0.07 \%$ 以上になるとスラグ中の鉄酸化物， $\mathrm{MnO}$, お よび $\mathrm{SiO}_{2}$ はほ核笔全に還元されて $3 \mathrm{CaO} \cdot \mathrm{Al}_{2} \mathrm{O}_{3}, 12$ $\mathrm{CaO} \cdot 7 \mathrm{Al}_{2} \mathrm{O}_{3}$, 近傍の組成仙なている。これらの反応 において $\mathrm{CaO}(+\mathrm{MgO})$ は 55 60\% の範困であり， $\mathrm{Al}$ による $\mathrm{CaO}$ の雀元反心起こつてないことがわか ろ.

次に鋼中に $\mathrm{N}$ と転炡スラグを薄鋼板で包み溶鋼中に 押迟し擤排し，溶解した絬果を Fig. 10 亿示す。これに よると sol. Al が $0.030 \%$ 以上から鋼中 $\mathrm{Si}$ の上昇が みられるが，これは鋼中に両者を同時に添加したため $\mathrm{Al}$ が溶解する将期に局部的に $\mathrm{Al}$ 濃度の高い部分で遗 元反伈が起つたものと考光られる。しかし欠陥部に久ら れる介在物は $\mathrm{Al}_{2} \mathrm{O}_{3}$ が $50 \sim 80 \%$ の高融点の $\mathrm{CaO}$ $\mathrm{Al}_{2} \mathrm{O}_{3}\left(\mathrm{CaO} .2 \mathrm{Al}_{2} \mathrm{O}_{3}, \mathrm{CaO} \cdot 6 \mathrm{Al}_{2} \mathrm{O}_{3}\right)$ でありスラグが鋼中

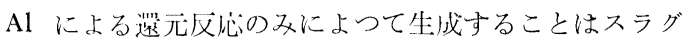
中の $\mathrm{CaO}$ 含有显から考光にくい、すなわち，このよう
飞生成した低融点の $\mathrm{CaO}-\mathrm{Al}_{2} \mathrm{O}_{3}$ 系介在物に脱酸生成物 の $\mathrm{Al}_{2} \mathrm{O}_{3}$ が加わり, 介在物中の $\mathrm{Al}_{2} \mathrm{O}_{3}$ の濃度が増加 乙, 高融点の $\mathrm{CaO}-\mathrm{Al}_{2} \mathrm{O}_{3}$ 系介在物になつたものと考兄 なければならない。

\section{5 実操業結果}

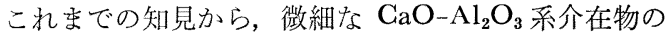
対策は，連続鋳造プロセスに损いて不可避である親鍋交 換といら非定常作業に括汀る問題解決が重要であること がわからた。 この対策としてタンディッシュを $60 \mathrm{t}$ と 大型化にしそれを有効に使つて介在物対策の機能をむた せた連鋳機Aおよび，タンディッシュは溶鋼の両ストラ ンドへの注ぎ分けを主目的とした従来型のままとし，そ の前に取鍋と同じ容量（互換性をもたせるため）の中間 鍋を配し，この中間鍋にスラグの流出防止，湯量調整な ぞ親鍋交換作業による非定常部を吸収させる機能をもた せた連鋳機 Bについて調查を行つた，その他の連鋳条件

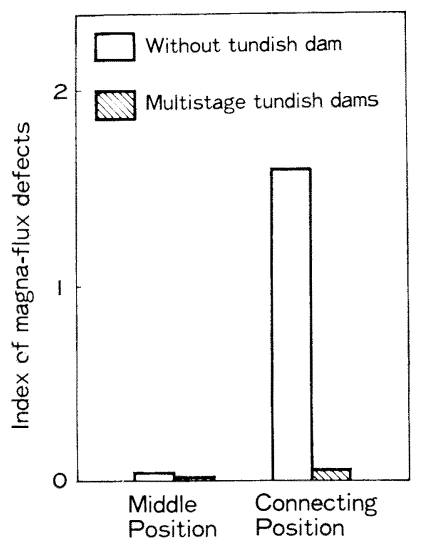

Fig. 11. Rate of magna-flux defects in tin products comparing without tundish dam and multistage tundish dams.

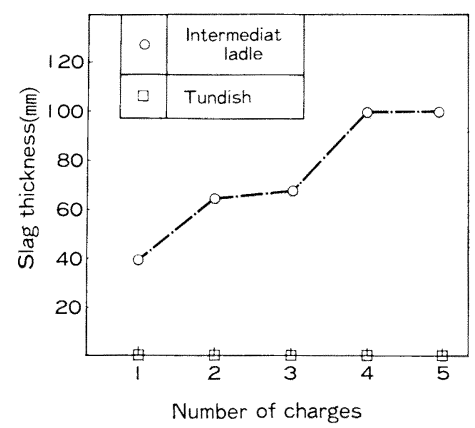

Fig. 12. Change of slag thickness in tundish and intermediate ladle in continuous-continuous casting. 


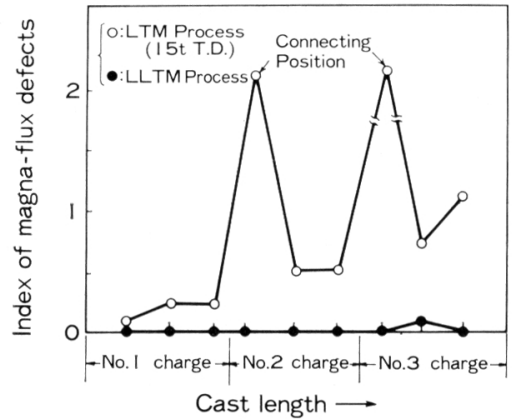

Fig. 13. Rate of magna-flux defects in tin products comparing LTM process (15t tundish) and LLTM process.

は, Table 2 に示すと和りであり，従来から述べられて いる溶鋼の清浄化，注入流の空気酸化，などの諸介在物 対策をとつている，連鋳機Aで製造した製品の磁粉探傷 結果を Fig. 11 に示す. 継目部での品質改善効果が大で あり,タンディッシュ㘿などの効果が明瞭にみられる. 連鋳機 Bについて中間鍋敊よびタンディッシュ内のスラ グ厚さの変化を Fig. 12 に示す. 中間鍋に括ける最低溶 鋼量を確保することにより, タンディッシュへのスラグ 流出がなく, さらに鍋交換时に括计る非定常作業は原理 的に解消され, 鍋交換に関係なく定常状態で鋳造可能で ある.この結果，Fig. 13 に示すように継目部に相当す る位置での変動が全くなく, 全鋳片にわたつて, 従来の レードルータンディッシューモールド (LTM 法) の方 式に比べて安定した品質が得られることが確認された.

\section{4. 考察}

\section{$4 \cdot 1 \mathrm{CaO}-\mathrm{Al}_{2} \mathrm{O}_{3}$ 系介在物の生成}

前記の結果から $\mathrm{CaO}-\mathrm{SiO}_{2}$ 系スラグと溶鋼中の $\mathrm{Al}$ との反応による $\mathrm{SiO}_{2}$ の還元について簡単な熱力学的検 討を行つた. Al による被還元性は, 酸素ポテンシャル の差の大きい順, すなわち $\mathrm{FeO}, \mathrm{MnO}, \mathrm{SiO}_{2}$, の順と なり $\mathrm{CaO}$ の還元は起らず, 反応は $\mathrm{SiO}_{2}$ の還元で律速 される。

溶鋼中の $\mathrm{Al}$ にる $\mathrm{SiO}_{2}$ の還元反応は（1）式で表 され， $\Delta G^{\circ}$ と平衡定数 $K$ との関係は学振推奨值を参考に すると（2）式が成り立つ.

$$
\begin{gathered}
3 \mathrm{SiO}_{2}+4 \mathrm{Al}=2 \mathrm{Al}_{2} \mathrm{O}_{3}+3 \mathrm{Si} \\
\log K=\frac{\left[\% \mathrm{Si} \cdot f_{\mathrm{si}}\right]^{3} \cdot a^{2} \mathrm{Al}_{2} \mathrm{O}_{3}}{a^{3} \mathrm{SiO}_{2} \cdot\left[\% \mathrm{Al} \cdot f_{\mathrm{Al}}\right]^{4}}=\frac{37630}{T}-6.0
\end{gathered}
$$

$f_{\mathrm{Si}}$, 反応生成物 $\mathrm{Al}_{2} \mathrm{O}_{3}$ の活量を 1 , 反応温度を 1580

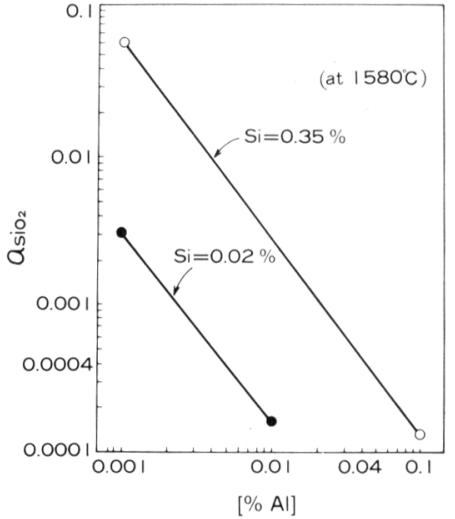

Fig. 14. Calculation of activity of $\left[\mathrm{SiO}_{2}\right]$ in slag in relation to $[\mathrm{sol} . \mathrm{Al}] \%$ at $1580^{\circ} \mathrm{C}$.

${ }^{\circ} \mathrm{C},[\% \mathrm{Si}]=0.35$ および $0.02(\mathrm{Al}$-キルド鋼) とし(2) 式より求めた $[\% \mathrm{Al}]$ と $a_{\mathrm{SiO}_{2}}$ の関係は，Fig. 14，のよ らになる。

CaO- $\mathrm{SiO}_{2}-\mathrm{Al}_{2} \mathrm{O}_{3} 3$ 元系に打忟 $a_{\mathrm{SiO}_{2}}$ の変化は, 大 谷 ${ }^{17)}$ の実験結果からスラグ組成は $a_{\mathrm{SiO}_{2}}$ に依存すること がわかる・以上のことから $\mathrm{SiO}_{2}$ が區湾還元される $a_{\mathrm{SiO}_{2}}$ の活量 0.0004 に対する $\mathrm{Al}$ は, $\mathrm{Si}=0.35 \%, 0.02$ \%に抢いて，それぞれ $0.040 \%, 0.005 \%$ となる・実験 結果による $\mathrm{SiO}_{2}$ の還元が認められた sol·Al が, 0.030 $\%$ 0.070\%とほ添同一の值を得た. また低炭素アルミ キルド鋼の場合は $\mathrm{Si}<0.02 \%$ とすると sol·Al は 0.005 \%から還元が起ると考えられる.

以上，転炉スラグと $\mathrm{Al}$ との反応により $\mathrm{sol} \cdot \mathrm{Al}$ が $0.030 \%$ 以上になると $\mathrm{SiO}_{2}$ の還元が起り， $0.070 \%$ 以

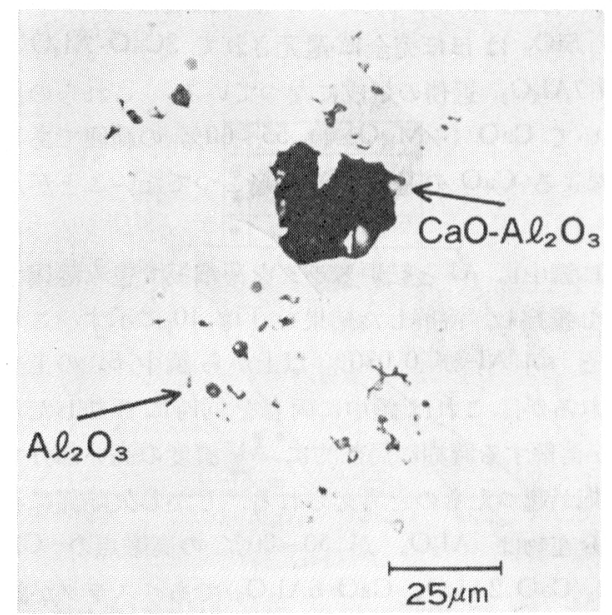

Photo. 2. Typical inclusions found in ladle after deoxydation by aluminium addition. 
上になると低融点の $\mathrm{CaO}-\mathrm{Al}_{2} \mathrm{O}_{3}$ 系 $\left(3 \mathrm{CaO} \cdot \mathrm{Al}_{2} \mathrm{O}_{3}, 12\right.$ $\left.\mathrm{CaO} \cdot 7 \mathrm{\Lambda l}_{2} \mathrm{O}_{3}\right)$ が仅成されることが判明した・しかし, 鋼 板の介在物には高融黛の $\mathrm{CaO} \cdot \mathrm{Al}_{2} \mathrm{O}_{3}, \mathrm{CaO} \cdot 2 \mathrm{Al}_{2} \mathrm{O}_{3}$, $\mathrm{CaO} \cdot 6 \mathrm{Al}_{2} \mathrm{O}_{3}$ が涩められた。これは, 転炉出鋼時におけ る $\mathrm{Al}$ 添加岮の $\mathrm{Al}$ が溶解する段階で鋼中に懸濁した転 暗大ラグとが文心し，低融点の $\mathrm{CaO}-\mathrm{Al}_{2} \mathrm{O}_{3}$ 系介在物が 生成され，これに脱酸作成物の $\mathrm{Al}_{2} \mathrm{O}_{3}$ が加わり $\mathrm{Al}_{2} \mathrm{O}_{3}$ 濃度が堵加し高融焦の $\mathrm{CaO}-\mathrm{Al}_{2} \mathrm{O}_{3}$ 系介在物となつたも のと考えられる。これらの介在物は, 取鍋内溶鋼におい てナでに生成している様子を Photo. 2 に示す. $\mathrm{CaO}$ $\mathrm{Al}_{2} \mathrm{O}_{3}$ 系介在物とその周团に $\mathrm{Al}_{2} \mathrm{O}_{3}$ クラスターが見ら れることから上述の上らな機構で高融点の $\mathrm{CaO}-\mathrm{Al}_{2} \mathrm{O}_{3}$ 系介在物が生成していることを寒付けている.

\section{2 スラグ系介在物の溶鋼中における 浮上についての} 考察

磁粉探傷火伯はトとしてスラグのたたきこみにより混 入した $100 \mu \mathrm{m}$ 程度の介在物であり, 容易に鋳型内に流 机込むことは前述のと和りである。

また, $100 \mu \mathrm{m}$ 程度の介在物は浮上速度が $0.3 \mathrm{~m} / \mathrm{min}$

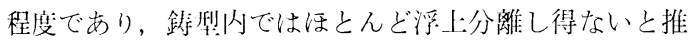
定される゙ ${ }^{18)}$. したがらてこれら大きさの介在物を減らす にはスラ少のたたさこみ防止に加えて溶鋼中での浮上分 離性を收清寸る必装がある. しかしながら通常のタンデ ィッシュでは取鍋沫:入流のかなりがタンディッシュ底部 に沿つて䓡咕間で鋳型に達するため，タンディッシュ内 の大部分は, デッドスペースとなり，このため取鍋注入 溶鋼のタンディッシュ内に括ける滞留時間の平均值が計 算侹より小となり浮上性の悪い介在物は鋳型内に流出し てしまう ${ }^{19)}$.とくに $100 \mu m$ 程度の介在物はタンディッ シュ底部からタンディッシュ湯而までの浮上時間が数分 程度であり，その影留は無視しがたく滞留時間分布の改 善が必嫳である。

そこでタンディッシュ内の溶鋼の滞留時間分布が 100 $\mu m$ 程度の介住物の浮上分離にどの程度影響するかを次
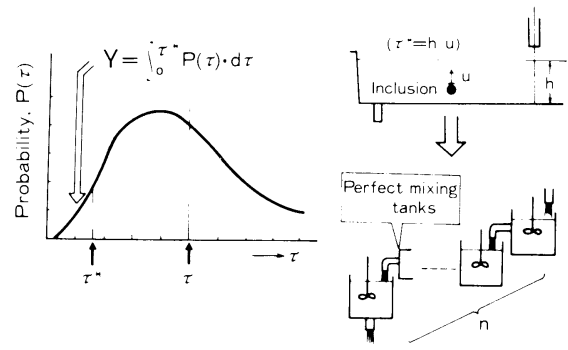

Fig. 15. Calculation model of floating out of inclusion in tundish or intermediate ladle.

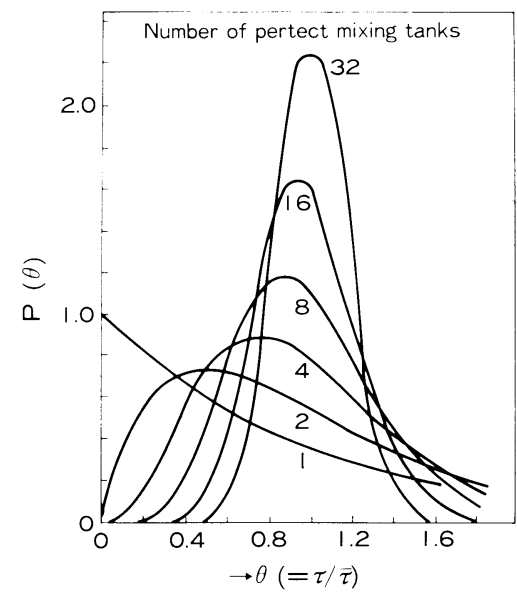

Fig. 16. Distribution of staying life of molten steel fragments in law of perfect mixing tanks.

の単純化したモデルで考察してみる.

まず，容器内の溶鋼の滞留時間分布（以下 $\tau$ 分布）を Fig. 15 に示すようにかりに逆混合がない完全混合槽列 の $\tau$ 分布に扣きかえてみる ${ }^{20)}$. この場合， $\tau$ 分布は，(3) 式であらわされ， $\tau$ 分布を規定するパラメータ槽数 $(n)$ の増加にともなつて Fig. 16 のようにてが小さなもの の割合は減つて計算平均滞留時間 $(\tau)$ を心とした正規 分布に近づく.

$$
P(\theta)=\frac{n^{n+1} \cdot \theta^{n-1} \cdot \exp (-n \theta)}{n !}
$$

ここで $\theta=\tau / \bar{\tau}$ であり $P(\theta)$ は滞留時間が $\theta \cdot \tau$ で ある取鍋注入溶鋼素片の割合である. 一方介在物の分離 条件として

（1） $\tau$ がある臨界の $\tau^{*}$ より大きい溶鋼素片中の介 在物は分離する.

（2） $\tau^{*}$ は浮上速度が $u$ なる介在物が湯面高さ $(h)$ を浮上するのに要する時間に等しい.

と仮定すると介在物の鋳型への流出率 $(Y)$ は $(4)$ 式から 推定し得る.

$$
Y=\int_{0}^{\tau^{*} / \bar{\tau}} P(\theta) \cdot d \theta
$$

なお介在物の浮上速度 $(u)$ は, $\mathrm{CaO}-\mathrm{Al}_{2} \mathrm{O}_{3}$ 系の球状 介在物を前提として求めた Fig. 17 の関係を用いた.

Fig. 18 に槽数すなわち Fig. 16 の $\tau$ 分布に対応し て求めた介在物の鋳型への流出率を示した。 $\tau$ 分布の改 善効果はきわめて大であり，とくに $300 \mu \mathrm{m}$ 程度以上の 介在物の浮上分離に対する効果は大きく, 従来から報告 されている介在物の粒径分布とかなり一致している12).

これに対し，100 $\mu \mathrm{m}$ 程度の介在物では相対的に浮上 


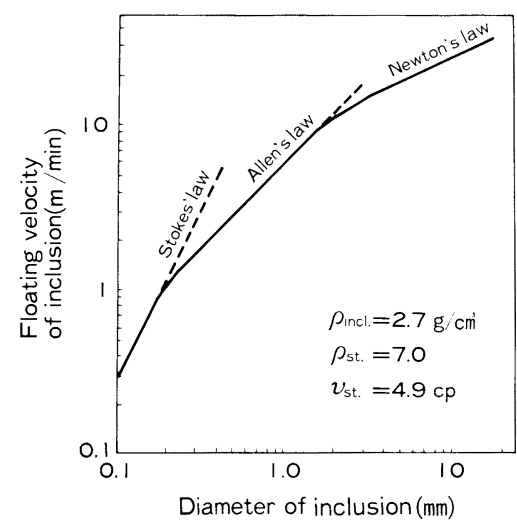

Fig. 17. Relation between floating velocity and diameter of inclusion.

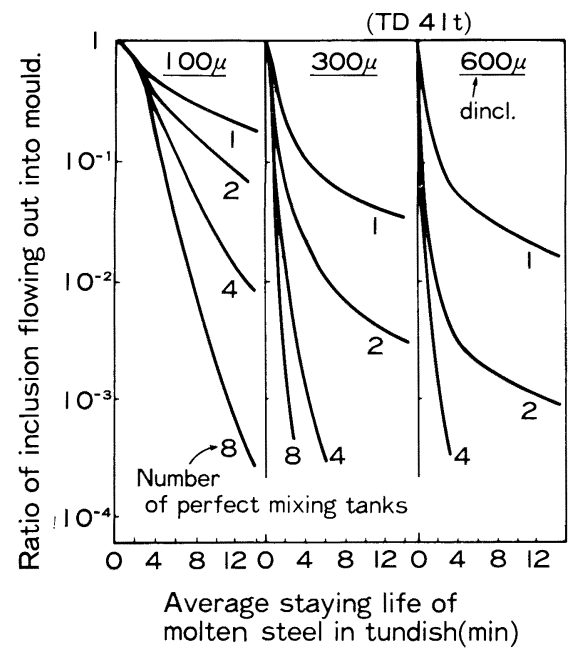

Fig. 18. Influence of $\tau$-distribution in tundish on ratio of inclusion flowing out into mould.

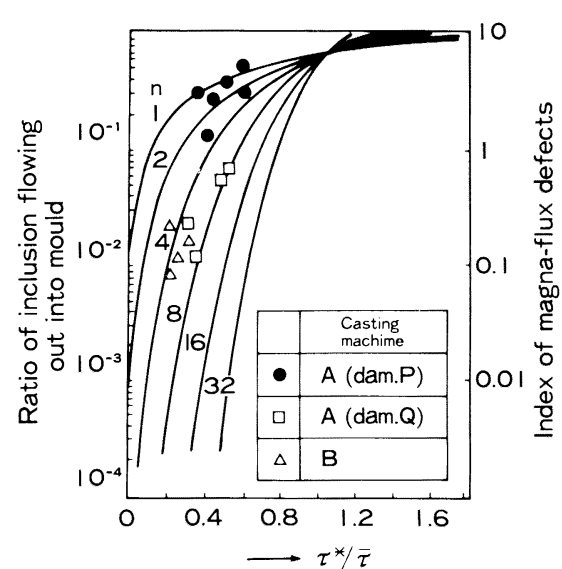

Fig. 19. Relation between $\tau^{*} / \bar{\tau}$ and ratio of inclusion flowing out into mould.

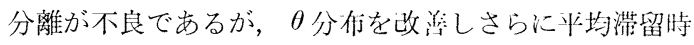
間を確保すれば，かなり鋳型への流出摔を減少し得るこ とが推定される.

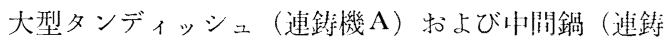
機 B ）の場合の $\tau^{*} / \bar{\tau}$ を Table 5 に示す. この优を用い て Fig. 19 に多段㹇を設䁒した大型タンディッシュの 場合，抢よび LLTM 操栄の場仝について磁粉探傷火陷 の発生と $\tau^{*} / \bar{\tau}$ との関係を示した. ここでは, 介伍物径

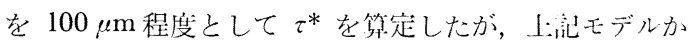
ら推定した結果と同じ倾问を示しており，多段揠Qは咹 $\mathrm{P}$ に比べて $\mathrm{n}$ が 4〜8 程度に相当与る $\theta$ 分们まで改善さ れた結果, 磁粉探傷火陥の発生が減少したと推定され る.また LLTM 操業においても $\theta$ 分们の收善とともに 溶鋼の滞留時間延長による效果も大きく，磁粉探傷欠陌 の発生が減少したものと推定できる.

Table 5. Estimation of $\tau^{*} / \bar{\tau}$ values in tundish and intermediate ladle.

\begin{tabular}{|c|c|c|c|c|c|c|c|c|c|c|}
\hline & \multirow{2}{*}{ Position } & \multirow{2}{*}{$\begin{array}{c}\text { Capacity } \\
(\mathrm{t})\end{array}$} & \multirow{2}{*}{$\begin{array}{l}\text { Bath } \\
\text { depth } \\
(\mathrm{m})\end{array}$} & \multicolumn{2}{|c|}{ Slab size $(\mathrm{mm})$} & \multirow{2}{*}{$\begin{array}{l}\text { Casting } \\
\text { speed } \\
(\mathrm{m} / \mathrm{min})\end{array}$} & \multirow{2}{*}{$\begin{array}{l}\text { Casting } \\
\text { rate } \\
(\mathrm{t} / \mathrm{min})\end{array}$} & \multirow{2}{*}{$\tau^{*}$} & \multirow{2}{*}{$\tau$} & \multirow{2}{*}{$\tau * / \Sigma$} \\
\hline & & & & Width & Thickness & & & & & \\
\hline \multirow{2}{*}{ Tundish } & $\begin{array}{l}\text { Middle } \\
\text { position }\end{array}$ & 60 & 1.2 & 200 & 1950 & 1.4 & 8.5 & 4 & 7.1 & 0.56 \\
\hline & $\begin{array}{l}\text { Connecting } \\
\text { position }\end{array}$ & 40 & 0.8 & 200 & 1950 & 1.1 & 6.7 & 3 & 6.0 & 0.50 \\
\hline \multirow{2}{*}{$\begin{array}{l}\text { Intermediate } \\
\text { ladle }\end{array}$} & $\begin{array}{l}\text { Middle } \\
\text { position }\end{array}$ & 250 & 2.95 & 245 & 1780 & 1.3 & 8.8 & 9.8 & 28.4 & 0.36 \\
\hline & $\begin{array}{c}\text { Connecting } \\
\text { position }\end{array}$ & 140 & 1.5 & 245 & 1780 & 1.3 & 8.8 & 5 & 15.9 & 0.31 \\
\hline
\end{tabular}




\section{5. 結}

\section{$\overline{\overline{⿳ 亠 二 口}}$}

菖い清浮性を装求するDI盾用素材を多速鋳で安定し て製造する技術を確立するため，基礎的調查を行つた絬 果, 次のことがわからた.

(1) DI 往加「時のフランジ割れ 原因は 50〜150 $\mu \mathrm{m}$ 程度の主として $\mathrm{CaO}-\mathrm{Al}_{2} \mathrm{O}_{3}$ 系の微細な介在物であ る.この検出方法として, 磁粉探傷法は十分な検出精度 を名つ。

(2) $\mathrm{CaO}-\mathrm{Nl}_{2} \mathrm{O}_{3}$ 系介在物は，製鋼スラグが鋼中に 卷き込末れ鋼中 $\mathrm{Al}$ によつて還元され，脱酸生成物の $\mathrm{Al}_{2} \mathrm{O}_{3}$ と合体したものである.この現象は sol. Al が $0.005 \%$ 以上で発生すると考えられる.

(3) $\mathrm{CaO}-\mathrm{Al}_{2} \mathrm{O}_{3}$ 系介在物の原因は, タンディッシ ュスラグが後鍋の溶鋼流によつてたたさこまれることに よる寄与率が高い。

（4）連々鋳における継日部も含めた品質対策とし てタンディッシュの大型化と多段垵による浮上促進, あるいは中间鍋を配した継目部のない鋳造方式である LLTM 法によつて上記の微細な介在物対策をとつたと ころ，いずれも频著な品質の问上が確認された。

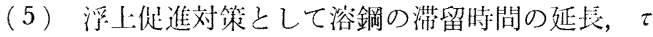
分仯の收流刘果で説明できる.

終わりに臨及，本研究の遂行にあたつて御協力をいた だいた各位に深く感射します。

\section{交献}

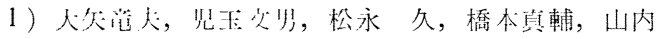
秀樹：鉄之舸，63 (1977)，S89

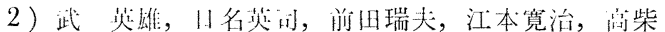

倍元，山崎脂次蚛：鉄と鋼，66（1980） S 184

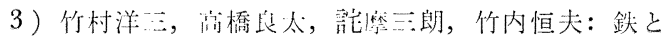
鋼，64 (1978) S 127

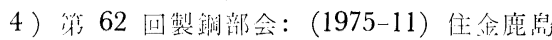

5 ）竹村洋三，高橋良太，野呂克拦，加滕輝茳：鉄之 銅，65 (1979)，S 652

6 ）踰木健一郎，江白涁夫，仲村秀夫，森耐介，三 代解嗣，飯田義治：鉄と鋼，61（1975)，p. 2805

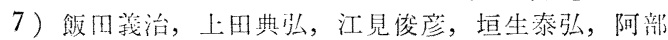
英夫，牦南秀夫，芳賀雄䖉，久々湊英雄：川崎製 鉄技報，8(1976)，p. 1

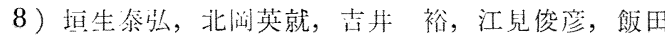
義治，上汀典弘：鉄と銅，62 (1976)，p.1803

9 ) 田阪 興，伊藤幸重，前出弘文：鉄と銅，63 (1977), p. 1279

10）第 54 回製鋼部会：(1972）新日鉄室蘭

11）松永吉之助，波木周和，荒不泰治：鉄と釗，59 (1973)，p. 72

12) 熊井浩, 広本健, 松永 久, 大橋徹虾, 大野 唯嘎：鉄と銅，60 (1974)，p. 926

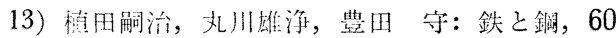
(1974), p. 943

14）第 54 回製鎑部会：(1972）新日鉄八幡

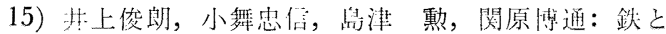
鎆，61 (1975)，S 90

16）主岩俊势，荒不泰汸，滕野允克，松野二三蚛：鉄 と䑪，58 (1972)，p. 2078

17）大行正康：鉄冶企熱力兴（1971），p. 151 [日刊 工箖社]

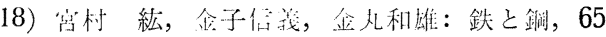
(1979)，S 229

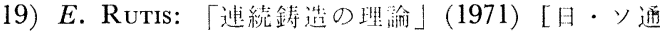
伯社:]

20) J. Szekely: Rate Phenomena in Process Metallurgy (1971) [Wiley-interscience] 